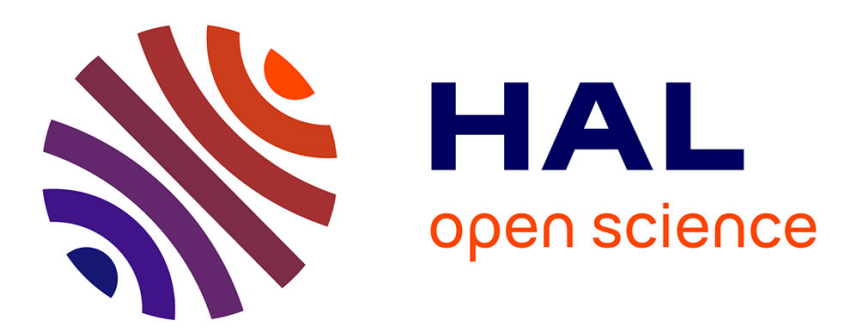

\title{
Effect of sodium chloride concentration on the heat resistance and recovery of Salmonella typhimurium
}

Pilar Manas, Rafael Pagan, Ivan Leguérinel, Santiago Condon, Pierre Mafart, Francisco Sala

\section{- To cite this version:}

Pilar Manas, Rafael Pagan, Ivan Leguérinel, Santiago Condon, Pierre Mafart, et al.. Effect of sodium chloride concentration on the heat resistance and recovery of Salmonella typhimurium. International Journal of Food Microbiology, 2001, pp.209-216. hal-00654646

\section{HAL Id: hal-00654646 \\ https://hal.univ-brest.fr/hal-00654646}

Submitted on 22 Dec 2011

HAL is a multi-disciplinary open access archive for the deposit and dissemination of scientific research documents, whether they are published or not. The documents may come from teaching and research institutions in France or abroad, or from public or private research centers.
L'archive ouverte pluridisciplinaire HAL, est destinée au dépôt et à la diffusion de documents scientifiques de niveau recherche, publiés ou non, émanant des établissements d'enseignement et de recherche français ou étrangers, des laboratoires publics ou privés. 


\title{
Effect of sodium chloride concentration on the heat
}

\section{resistance and recovery of}

\section{Salmonella typhimurium.}

\author{
Mañas P. ${ }^{\mathrm{a}}$, Pagan R. ${ }^{\mathrm{a}}$, Leguérinel $\mathrm{I}^{\mathrm{b}}{ }^{*}$ \\ ,Condon S. ${ }^{\text {a }}$, Mafart P. ${ }^{\mathrm{b}}$, Sala F. ${ }^{\mathrm{a}}$
}

${ }^{\text {a }}$ Tecnologia de los alimentos, Facultad de Veterinaria, Universidad de Zaragoza, C/Miguel Servet, 177, 50013 Zaragoza, SPAIN

Tel 976.76.21.32 Fax 976.76.15.90 e mail : manas@ posta.unizar.es

${ }^{\mathrm{b}}$ Laboratoire Universitaire de Microbiologie Appliqué de Quimper Pôle Universitaire de Creach Gwen F29000 Quimper, FRANCE

Tel 33.02.98.10.0061 e mail : guerinel@univ-brest.fr

* Corresponding author 


\begin{abstract}
The survival of Salmonella typhimurium (ATCC 13311) heated and recovered in media with $0 \%, 1 \%, 2 \%, 3 \%, 4 \%$ or $5 \%$ added sodium chloride was investigated. A protective effect in the heating medium and an inhibitory effect in the recovery medium were observed. The results showed an interaction between the effect, on D58 values, of sodium chloride concentration in both media. Lower concentration in the heating media led to a greater effect of the sodium chloride concentration in the recovery media. When the sodium chloride concentration was the same in both media, the protective effect exerted in the heating media prevailed over its inhibitory effect in the recovery media.
\end{abstract}

Keywords : $\underline{\text { Salmonella typhimurium }}$, Sodium chloride, Heat treatment, Recovery, Modelling 


\section{INTRODUCTION}

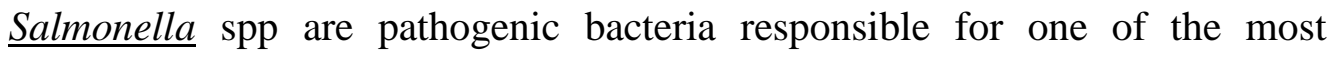
frequent foodborne diseases. Since 1970, the number of isolates of different

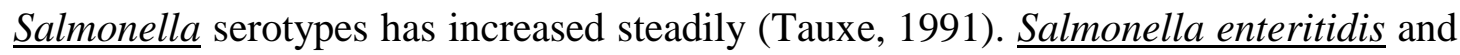
Salmonella typhimurium are the serotypes most frequently involved in food poisoning outbreaks. Although, S. enteritidis became more important in the late 80 's and early

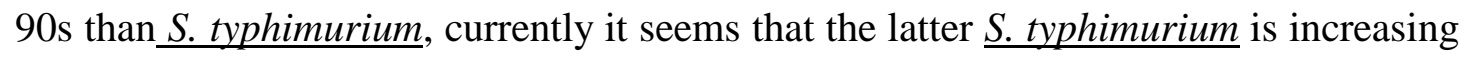
species (Zeidler, 1997). This micro-organism is mostly found in foods of animal origin and its inactivation in foods can be achieved by an adequate heat treatment.

The addition of sodium chloride to foods to inhibit or delay microbial growth is a very old and widespread practice. However, some micro-organisms are able to grow even in media with high concentrations of sodium chloride. $\underline{\text { S. typhimurium, at }}$ its optimum growth temperature, is able to develop in media with $7 \%$ sodium chloride (Matches and Liston, 1979). A mathematical model of $\underline{S \text {. typhimurium }}$ growth at different temperatures in media of different $\mathrm{pH}$ with different sodium chloride concentrations was developed by Gibson et al. (1988). This model was worked out with data obtained with unheated cells. The behaviour of heated cells in these media is not known.

Heat treatments kill a fraction of a bacterial population, but they also generate damaged cells. The ability of heated cells to survive depends on the recovery conditions. If they are favourable, they can repair heat damage and grow. Heat is supposed to damage some cellular structures (cytoplasmic membrane, ribosomes, RNA, enzymes...). As a consequence, cell membrane permeability is altered and leads 
to leakage of proteins, aminoacids, potassium ions etc... Heat injured cells also become more sensitive to sodium chloride. The addition of sodium chloride to the recovery medium has been used by authors to measure the proportion of heat damaged cells. Tomlins and Ordal (1976) and Mackey and Derrick (1982) have enumerated heat damaged $\underline{S \text {. typhimurium }}$ cells by using recovery media with added 2 and $3 \%$ of sodium chloride, respectively. Therefore, the addition of sodium chloride to the recovery medium leads to the estimation of lower apparent $\mathrm{D}$ values than those calculated using an optimum recovery medium.

It has been shown that heat resistance of Salmonella, as that of other bacterial species, can increase if cells are preincubated $(\mathrm{Ng}, 1982)$ or heated in low water activity media, such as those obtained by adding sodium chloride (Cotterill and Glauert, 1969, Palumbo et al., 1995) or other solutes such as sucrose, glycerol and fructose (Goepfert et al., 1970, Sumner et al., 1991). In most of these studies, the solute concentrations were very high ( $>6 \%$ of $\mathrm{NaCl}$ ). Such concentrations are only found in some special foods like egg products, sausage, ham. The conclusions of these investigations cannot be extrapolated to the majority of food products. The influence of low sodium chloride concentrations on the heat resistance of $\underline{\text { S. typhimurium is not }}$ well known. When salt is added to the recovery medium it has the opposite effect (Tomlins and Ordal, 1976, Mackey and Derrick, 1982). Published data do not allow us to predict which of the effects is going to prevail at the sodium chloride concentrations of most foods.

The purpose of this investigation was to determine the influence of sodium chloride concentration in the heating and recovery medium on the capacity of $\underline{S}$. typhimurium to survive heat treatment . 


\section{MATERIALS AND METHODS}

\section{Bacterial culture and media}

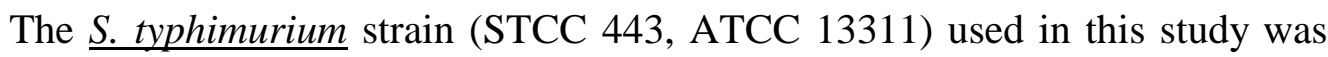
supplied by the Spanish Type Culture Collection. It was maintained on slants of Tryptic Soy Agar (Biolife; Milan; Italy) with $0.6 \%$ of Yeast Extract added (Biolife) (TSAYE).

A broth subculture was prepared by inoculating with one single colony from a plate, a test tube containing $5 \mathrm{ml}$ of sterile Tryptic Soy Broth (Biolife) with $0.6 \%$ of Yeast Extract added (Biolife) (TSBYE). After inoculation, this tube was incubated at $37^{\circ} \mathrm{C}$ for 18 hours. Erlenmeyer flasks $(250 \mathrm{ml})$ with $50 \mathrm{ml}$ of sterile TSBYE were inoculated with this subculture to a final concentration of $10^{6}$ cells $/ \mathrm{ml}$ approx. The flasks were then incubated for $30 \mathrm{~h}$. at $37^{\circ} \mathrm{C}$ under agitation (130 rev/min) (Selecta; mod. Rotabit; Spain). After that time cells had reached stationary phase and maximum thermo-tolerance. Cell suspensions thus prepared were stored under refrigeration, without agitation, for up to $30 \mathrm{~d}$. Previous experiments showed that, during storage, heat resistance did not vary (data not shown).

\section{Heat treatments}

Heat treatments were carried out in duplicate in a thermoresistometer TR-SC as described elsewhere (Condón et al. 1993). TSBYE medium with 0\%, 1\%, 2\%, 3\%, $4 \%$, and $5 \%$ added $\mathrm{NaCl}$ (Probus, Barcelona, Spain) were used as heating media. 
Once the heating medium $(350 \mathrm{ml})$ temperature had attained stability $\left(\mathrm{T} \pm 0.05^{\circ} \mathrm{C}\right)$, it was inoculated with $0.2 \mathrm{ml}$ of an adequately diluted cell suspension. During heat treatments $2 \mathrm{ml}$ samples were periodically collected into sterile test tubes. From each one of these tubes an aliquot of $0.1 \mathrm{ml}$ was immediately pour-plated in TSAYE containing $0 \%, 1 \%, 2 \%, 3 \%, 4 \%$, and $5 \% \mathrm{NaCl}$ added (TSAYE-S).

\section{Incubation of heated samples and survival counting}

After heat treatments, the plates were incubated at $37^{\circ} \mathrm{C}$ for 48 hours. Previous experiments showed that longer incubation times did not increase survivor counts.

Colonies were counted with an Image Analyser Automatic Counter (Protos, Analytical Measuring Systems, Cambridge, UK) as described elsewhere (Condón $\underline{e t}$ al. 1996).

Heat-damaged cells were estimated by the difference in the number of $\mathrm{CFU}$ formed by heated suspensions in TSAYE or TSAYE-S medium.

\section{Heat resistance parameters and data fitting}

$\mathrm{D}_{\mathrm{T}}$ values were calculated from the slope of the straight portion of survival curves. Survival curves were drawn by plotting log of number of survivors vs their corresponding heating times.

Correlation coefficients $\left(\mathrm{r}_{\mathrm{o}}\right)$ were calculated with the appropriate statistical package (Statview 512; D. Feldman and J. Gagnon, BrainPower Inc., Calabasas, CA). The statistical significance of differences $(\mathrm{p}>0.05)$ between $\mathrm{D}_{\mathrm{T}}$ values was tested as described by Steel and Torrie (1960). 
Multiple linear regressions used to fit polynomial models were carried out with the STAT-ITCF software (Institut Technique des Céréales et du Fourage, France).

\section{RESULTS AND DISCUSSION}

The effect of $\mathrm{NaCl}$ concentration in the heating and recovery media on the heat resistance (D values) of our $\underline{S \text {. typhimurium strain is shown in Figure 1. Salmonella }}$ heat resistance values published in literature can vary widely. The heat resistance of our strain heated in TSBYE and recovered in TSAYE $\left(\mathrm{D}_{58}{ }^{\circ} \mathrm{C}=0.4 \mathrm{~min}\right)$ was similar to that reported by D’Aoust et al. (1987) for several Salmonella strains.

The addition of sodium chloride to the heating medium led to higher $\mathrm{D}$ values, while sodium chloride addition to the recovery medium made them lower. These results are in agreement with those of other authors who also found that sodium chloride in the heating medium increased heat resistance of Salmonella (Cotterill and Glauert, 1969, Ng, 1982, Palumbo et al., 1995, Blackburn et al., 1997), while the recovery medium prevented the recovery of heat injured cells (Tomlins and Ordal, 1976, Mackey and Derrick, 1982)).

The magnitude of the effect of $\mathrm{NaCl}$ in the heating media on the heat resistance of our strain was similar to that reported by Baird-Parker et al. (1970) for other Salmonella serotypes. The addition of 5\% sodium chloride to the treatment medium increased the $\mathrm{D}_{58^{\circ} \mathrm{C}}$ value of our strain, recovered in TSAYE medium, from 0.4 to $0,66 \mathrm{~min}$. The higher microbial heat resistance in low water activity media has long been known (Corry ,1974). It is supposed to be due to a dehydration of the cell's 
cytoplasm (plamolysis), that would make enzymes and structural proteins inside more heat-stable (Corry;1974).

The addition of $5 \%$ sodium chloride to the recovery medium decreased $\mathrm{D}_{58}$ value of cells heat treated in TSBYE from 0.4 to $0.08 \mathrm{~min}$. This effect of sodium chloride in the recovery medium on the heat resistance of our strain could not be explained solely by the effect of the lower water activity of this medium on microbial growth . Perhaps, as suggested by some authors, heat treatment altered the selective permeability of cell membrane, allowing sodium chloride to go into the cytoplasm (Tomlins and Ordal, 1976) where it would interfere with vital metabolic activities. The action mechanisms of sodium chloride inside the cell remain still unknown. It has been suggested that sodium ions would inhibit some enzymatic activities (Kyzlink, V., 1990), and/or displace magnesium ions from ribosomes (Lee and Goepfert, 1975). Ribosomes would require magnesium ions to repair heat damage.

Recovery media with low sodium chloride concentrations (2-3\%), incapable of influencing growth of unheated cells, but inhibiting growth of heat damaged cells, have been used by authors to assess heat damage (Tomlins and Ordal, 1976; Mackey and Derick; 1982). By this procedure, the number of heat damaged cells is enumerated by the difference between the number of CFU developed by heated cells in recovery media with or without added sodium chloride.

However the influence of sodium chloride concentration in the recovery medium on $\mathrm{D}$ values obtained with cells heated in a medium with different concentrations of sodium chloride has never been investigated. 
Our results (Fig. 1) showed a clear interaction between the concentration of sodium chloride in both media. The magnitude of the difference between the $\mathrm{D}_{58}{ }^{\circ} \mathrm{C}$ values, obtained by heating in media with different concentrations of sodium chloride, was bigger for the highest concentrations of sodium chloride in the recovery medium. For recovery medium without sodium chloride added, $\mathrm{D}_{58}$ values obtained increased from 0.4 to 0.66 minute when heating medium sodium chloride concentration was increased from $0 \%$ to $5 \%$. However when a recovery medium with $5 \%$ of sodium chloride was used, $\mathrm{D}_{58}$ values obtained increased ten fold, from 0.08 to 0.80 minute. $\mathrm{D}_{58}{ }^{\circ} \mathrm{C}$ values were always lower for the highest concentration of sodium chloride in the recovery medium. However, this influence of sodium chloride concentration in the recovery medium on the magnitude of $\mathrm{D}_{58}{ }^{\circ} \mathrm{C}$ values obtained, was smaller for the highest sodium chloride concentration in the heating medium. In a medium with a $5 \%$ sodium chloride added it was almost slight. This interaction between the concentration of $\mathrm{NaCl}$ in both media is well illustrated by Figures 2 and 3. Survival curves obtained (Fig. 2) seemed to indicate that the damage inflicted in cells heat treated in a medium with a $1 \%$ sodium chloride added was quite different from that inflicted on cells in a heating medium with a $5 \%$ sodium chloride. In the cell suspension heat treated in a medium with $1 \%$ sodium chloride added, the percentage of damaged cells increased with heating time, as shown by the difference among counts obtained in a recovery medium with $1 \%$ or $5 \%$ added sodium chloride. However, in the cell suspension heat treated in a medium with a $5 \%$ sodium chloride added the percentage of damaged cells remained practically the same regardless of heating time (fig. 3). This behaviour is in agreement with the data of Mafart and Leguérinel (1997) who showed that recovery ratio was independent of heating time when the decimal reduction time was not reduced with regard to observed optimum recovery conditions. 
D values of Fig 1 could be fitted according to the following polynomial equation:

$$
\begin{aligned}
& \log D^{\prime}=0.4397+0.2824 x-0.1549 x^{2}+0.005543 y^{2}+0.02534 x y \\
& \text { with } \mathrm{r}^{2}=0,925
\end{aligned}
$$

where $\mathrm{x}$ was the sodium chloride concentration added to the heating medium and $y$, the salt concentration added to the recovery medium.

In practice, the food is both the heating and the recovery medium $(\mathrm{x}=\mathrm{y})$. Therefore the case in which $\mathrm{x}=\mathrm{y}$ is particularly interesting. Under these conditions, our polynomial model becomes:

$\log D^{\prime}=a_{0}+a_{1} x+a_{2} x^{2}$

This equation could be reparameterized to

$$
\log D^{\prime}=\log D_{0}-\frac{x}{x_{o p t}}\left(\log \frac{D_{0}}{D_{\max }}\right)\left(2 x_{o p t}-x\right)
$$

Where $\mathrm{D}_{0}$ denotes the $\mathrm{D}$ value without salt and $\mathrm{x}_{\mathrm{opt}}$ the $\mathrm{NaCl}$ concentration at which the $\mathrm{D}$ value is maximum (Dmax). The relationship between these values and coefficients $a_{0}, a_{1}$ and $a_{2}$ is illustrated in appendix. 
The inactivation rate of bacteria is supposed to be ruled by first order kinetics. However, deviations from the linearity of survival curves have been frequently reported (Cole et al., 1993, Condón et al., 1992). Some survival curves obtained in this investigation did not follow a strict logarithmic course of destruction and sometimes a clear biphasic profile was obtained. Comparing the curve corresponding to $1 \%$ sodium chloride in the heating medium and a $5 \%$ sodium chloride in the recovery medium with that corresponding to $5 \%$ in the heating and the recovery medium, the number of survivors after 5 seconds of treatment were, approximately the same (Figure 2). After that, cells heated in a 5\% sodium chloride medium showed much greater heat resistance than cells heated in a $1 \%$ sodium chloride medium. Perhaps the drop in counts after the first 5 seconds of heating in media containing $5 \%$ of $\mathrm{NaCl}$ could be due to an osmotic shock inactivating most (90\% aprox .) of cells in the suspension, the remaining showing a much higher heat resistance. It could also happen that heat resistance of cells in $1 \%$ and $5 \% \mathrm{NaCl}$ were the same, but cells in the 5\% suspension were able to adapt to the environment by dehydrating their cytoplasm, during the first five seconds. As a consequence, they would increase their heat resistance, and/or their capacity to repair heat damage. A similar adaptation phenomenon had been observed by Ng (1982), and Cotterill and Glauert (1969).

Whatever the reason, the magnitude of the decrease in counts after the first 5 seconds of treatment depended on the amount of sodium chloride added to heating medium (Fig 4). This drop in counts could be described by the following polynomial equation:

$$
\log \frac{N_{1}}{N_{0}}=-0.4287+0.1244 x-0.0385 x^{2}-0.0534 y^{2}+0.0478 x y
$$


with $\mathrm{r}^{2}=.0 .913$

where $\mathrm{x}$ represented the $\mathrm{NaCl}$ concentration added to the heating medium and $\mathrm{y}$, the $\mathrm{NaCl}$ concentration added to the recovery medium.

The number of survivor after any treatment time under all environmental conditions investigated could be calculated by the equation:

$$
\log N_{t}=\log N_{1}-\frac{(t-5)}{D^{\prime}}
$$

where D'values could be provided by equation 1 or 2 and $\mathrm{N}_{1}$ values by equation 3.

Fig. 5 illustrates ,for the whole count of the experimental design $(n=506)$, the relationship between the experimentally and the theoretically calculated survival counts. The correlation between both values was quite satisfactory $\left(\mathrm{r}^{2}=0,946\right)$.

As our results show, the effect on the survival of Salmonella typhimurium after a heat treatment, of the presence of $\mathrm{NaCl}$ in the medium (at least up to a concentration of 5\%) was very limited. The inhibiting effect of $\mathrm{NaCl}$ on heated cells was mostly compensated for the increase in heat resistance of cells during treatment. In some instances the addition of $\mathrm{NaCl}$ even increased the probability of survival. This was the case when the concentration of sodium chloride was the same in both media, as it is normally the case in foods. When the concentration of sodium chloride was the same in both media $(x=y)$ survival increased slightly.

Data presented in this work will help to predict the safety of salted cooked or pasteurised foods with regard to Salmonella typhimurium. 


\section{ACKNOWLEDGEMENTS}

The authors would like to acknowledge the Diputación General de Aragón (DGA) which awarded Pilar Mañas a predoctoral grant to carry out this investigation.

\section{REFERENCES}

Baird-Parker, A.C., Boothroyd, M., Jones, E., 1970. The effect of water activity on the heat resistance of heat sensitive and heat resistant strains of Salmonellae. Journal of Applied Bacteriology 33, 515-522.

Blackburn, C., Curtis, L.M., Humpheson, L., Billon C., McLure, P.J., 1997. Development of thermal inactivation models for Salmonella enteritidis and Escherichia coli $\mathrm{O} 157: \mathrm{H} 7$ with temperature, $\mathrm{pH}$ and $\mathrm{NaCl}$ as controlling factors. International Journal of Food Microbiology 38, 31-44.

Cole, M.B., Davies, K.W., Munro, G., Holyoak, C.D., Kilsby, D.C., 1993. A vitalistic model to describe the thermal inactivation of Listeria monocytogenes. Journal of Industrial Microbiology 12, 232-239.

Condón, S., García, M.L., Otero, A., Sala, F.J., 1992. Effect of culture age, preincubation at low temperature and $\mathrm{pH}$ on the thermal resistance of Aeromonas hydrohila. Journal of Applied Bacteriology 72, 322-326.

Condón, S., Arrizubieta, M.J., Sala, F.J., 1993. Microbial heat resistance determinations by the multipoint system with the thermoresistometer TR-SC. Improvement of this methodology. Journal of Microbiology Methods 18, 357-366. 
Condón, S., Palop, A., Raso, J., Sala, F.J., 1996. Influence of the incubation temperature after heat treatment upon the estimated heat resistance values of spores of Bacillus subtilis. Letters in Applied Microbiology 22, 149-152.

Corry, J., 1974. The effect of sugars and polyols on the heat resistance of Salmonellae. Journal of Applied Bacteriology 37, 31-43.

Cotterill, O.J., Glauert, J., 1969. Thermal resistance of Salmonellae in egg yolk products containing sugar or salt. Poultry Science 48, 1156-1166.

D’Aoust, J.-Y., Emmons, D.B., McKellar, R., Timbers, G.E., Todd, E.C.D., Sewell,

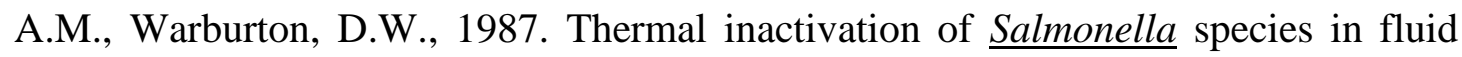
milk. Journal of Food Protection 50 (6), 494-501.

Gibson, A.M., Bratchell, N., Roberts, T.A., 1988. Predicting microbial growth: growth responses of a Salmonellae in a laboratory medium as affected by $\mathrm{pH}$, sodium chloride and storage temperature. International Journal of Food Microbiology 6, 155178.

Goepfert, J.M., Iskander I.K., Amundson, C.H., 1970. Relation of the heat resistance of Salmonellae to the water activity of the environment. Applied Microbiology 19, 429-433.

Klyzlink, V., 1990. Principles of food preservation. In : Series Developments in food Science, vol. 22. Elsevier Science, Amsterdam. 
Lee, A.C., Goepfert, J.M., 1975. Influence of selected solutes on thermally induced death and injury of Salmonella typhimurium. Journal of Milk Food Technology 38 (4), 195-200.

Mackey, B.M., Derrick, C.M., 1982. The effect of sub-lethal injury by heating, freezing, drying and gamma-radiation on the duration of the lag phase of Salmonella typhimurium. Journal of. Applied Bacteriology 53, 243-251.

Mafart, P. and Leguérinel, I., 1997. Modelling the heat stress and the recovery of bacterial spores. International Journal of Food Microbiology 37, 131-135.

Matches J.R. and Liston, J., 1972. Effects of incubation temperature on the salt tolerance of Salmonella. Journal of Milk Food Technology 35 (1), 39-44.

Ng, H., 1982. Development of high heat resistance in Arizona neotype by preincubation at $35^{\circ} \mathrm{C}$ in media containing $\mathrm{NaCl}$. Applied and. Environmental Microbiology 43 (6), 1294-1299.

Palumbo, M.S., Beers, S.M., Bhaduri, S., Palumbo, S.A., 1995. Thermal resistance of

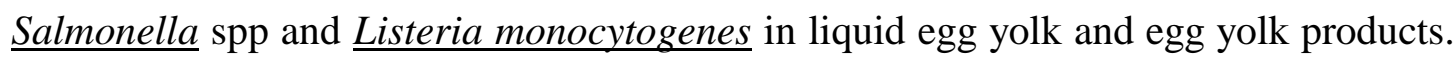
Journal of Food Protection 58 (9), 960-966.

Steel, R.G.D., Torrie, J.H., 1960. Principles and procedures of statistics. McGraw-Hill Book Company Inc., New York. 
Sumner S.S., Sandros, T.M., Harmon, M.C., Scott, V.N., Bernard, D.T. (1991). Heat resistance of Salmonella typhimurium and Listeria monocytogenes in sucrose solutions of various water activities. Journal of Food Science 56 (6), 1741-1743.

Tauxe, R.V., 1991. Salmonella: a postmodern pathogen. Journal of Food Protection $54(7), 563-568$.

Tomlins, R.I., Ordal, Z.J., 1976. Thermal injury and inactivation in vegetative bacteria. In : "Inhibition and inactivation of vegetative microbes" (Ed.) Skinner, F.A. and Hugo, W.B. :The Society for Applied Bacteriology Symposium Series, no. 5. Academic Press, London, pp 153-190.

Zeidler, G., 1997. New light on foodborne and waterborne diseases. World Poultry 13 (9), 49-53. 


\section{APPENDIX}

Reparameterization of polynomial model

The data were fitted according to a simple polynomial model :

$\log D=a_{0}+a_{1} x+a_{2} y+a_{3} x^{2}+a_{4} y^{2}+a_{5} x y$

$\mathrm{x}:[\mathrm{NaCl}]$ in the heat treatment medium

$\mathrm{y}:[\mathrm{NaCl}]$ in the recovery medium

In the case of pasteurized foods, the recovery medium is also the heating menstrum then, $x=y$

The model becomes :

$\log D=a_{0}+a_{1} x+a_{2} x^{2}$

with according to the data,

$$
\begin{aligned}
& a_{0}=-0.4397 \\
& a_{1}=0.1275 \\
& a_{2}=-0.01317
\end{aligned}
$$

The coefficient do not have any physical or biological significance, so that the following reparameterization was proposed.

1) Without $\mathrm{NaCl}, \mathrm{x}=0$ and $\log \mathrm{D}=\log \mathrm{D}_{0}$

(D-value without salt $\mathrm{a}_{0}=\log \mathrm{D}_{0}$ ) 
2) $\frac{d(\log D)}{d x}=a_{1}+a_{2} x$

If $\mathrm{x}_{\mathrm{opt}}$ is the $\mathrm{NaCl}$ concentration at which the $\mathrm{D}$-value is maximum $\left(\mathrm{D}=\mathrm{D}_{\max }\right)$

$$
a_{1}+2 a_{2} x_{\text {opt }}=0 \Rightarrow a_{1}=-2 a_{2} x_{\text {opt }}
$$

$\log D=\log D_{0}-2 a_{2} x_{\text {opt }} x+a_{2} x^{2} \Rightarrow \log D=\log D_{0}-a_{2} x\left(2 x_{\text {opt }}-x\right)$

3) $\log D_{\max }=\log D_{0}-a_{2} x_{o p t}^{2} \Rightarrow a_{2}=\frac{1}{x_{o p t}^{2}} \log \frac{D_{0}}{D_{\max }}$

The reparameterized model is then :

$\log D=\log D_{0}-\frac{x}{x_{o p t}^{2}}\left(\log \frac{D_{0}}{D_{\text {max }}}\right)\left(2 x_{o p t}-x\right)$

with $D_{0}=10^{a_{0}}=0.363 \mathrm{~min}$

$$
\begin{aligned}
& x_{o p t}=-\frac{a_{1}}{2 a_{2}}=4.84 \% \\
& D_{\max }=10^{a_{0}-a_{2} x_{o p t}^{2}}=0.739 \mathrm{~min}
\end{aligned}
$$




\section{Figure legends}

Fig. 1. Influence of $\mathrm{NaCl}$ concentration on the heating and recovery media on $\mathrm{D}_{58}$ values of $\underline{\text { S. typhimurium. }}$.

Fig. 2. Survival curves at $58^{\circ} \mathrm{C}$ of $\underline{S}$. typhimurium heated in TSBYE added with $1 \%$ $\mathrm{NaCl}$ (closed symbol) or $5 \% \mathrm{NaCl}$ (opened symbol) the recovered medium is TSAYE added with $1 \%$ ( circle ) and $5 \% \mathrm{NaCl}$ added (square).

Fig. 3. Ratio of number of UFC for recovery conditions $5 \% \mathrm{NaCl}$ added / $1 \% \mathrm{NaCl}$ added, at different heating time at $58^{\circ} \mathrm{C}$ in TSBYE with $1 \% \mathrm{NaCl} \bigcirc$ and $5 \% \mathrm{NaCl}$ added

Fig. 4. Influence of $\mathrm{NaCl}$ concentration on the heating and recovery media on $\underline{S}$. typhimurium counts obtained after 5 seconds of treatment.

Fig. 5. Correlation between experimentally and theoretically predicted counts $(n=506)$. 
Figure 1

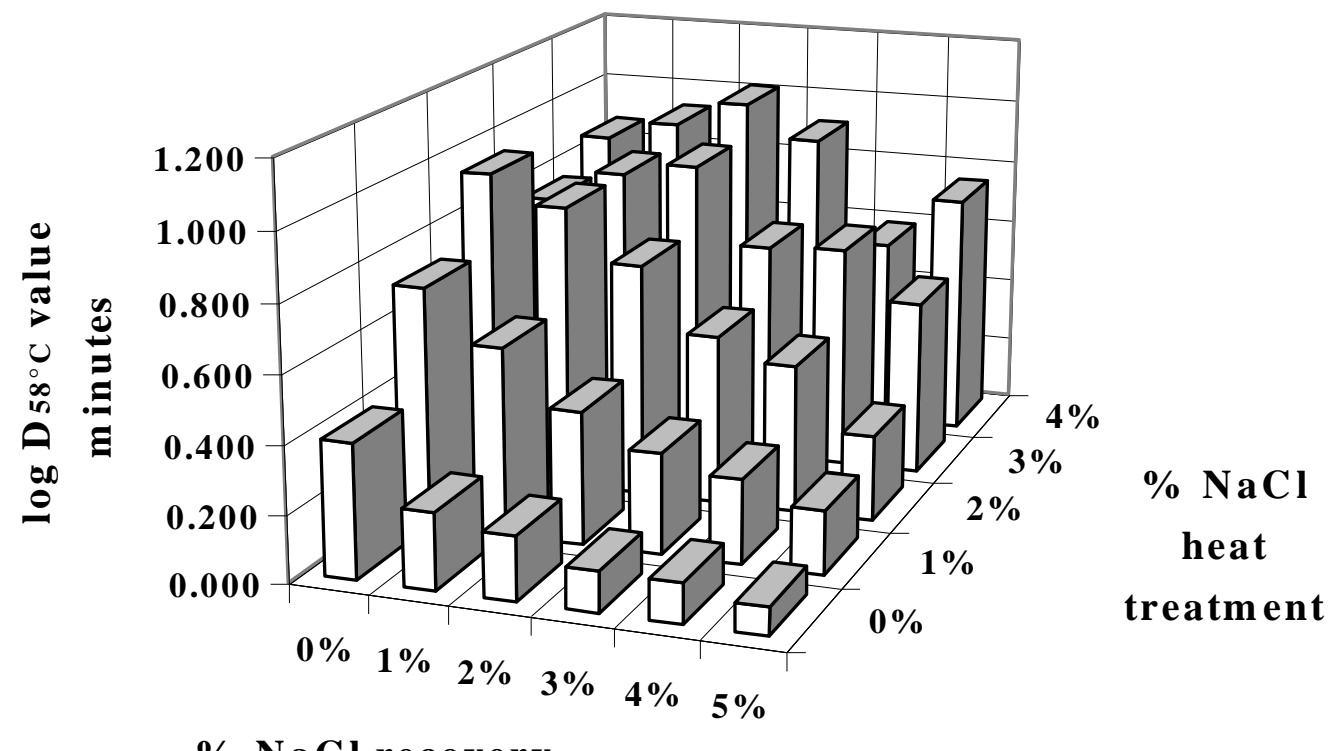

\% NaCl recovery 
figure 2

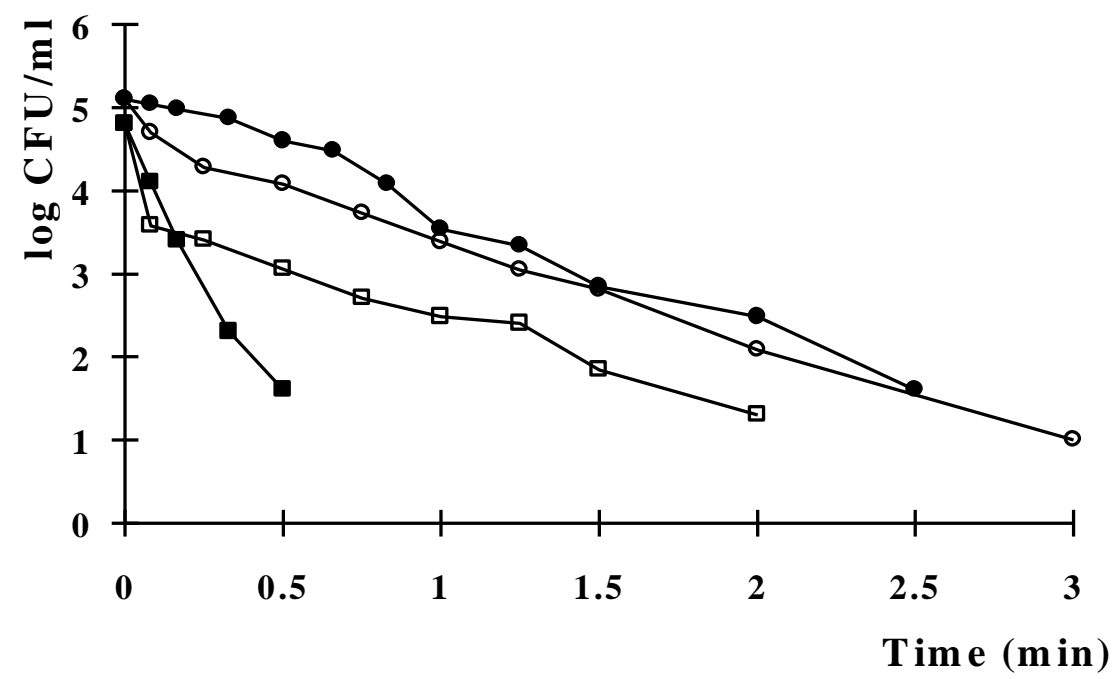


figure 3

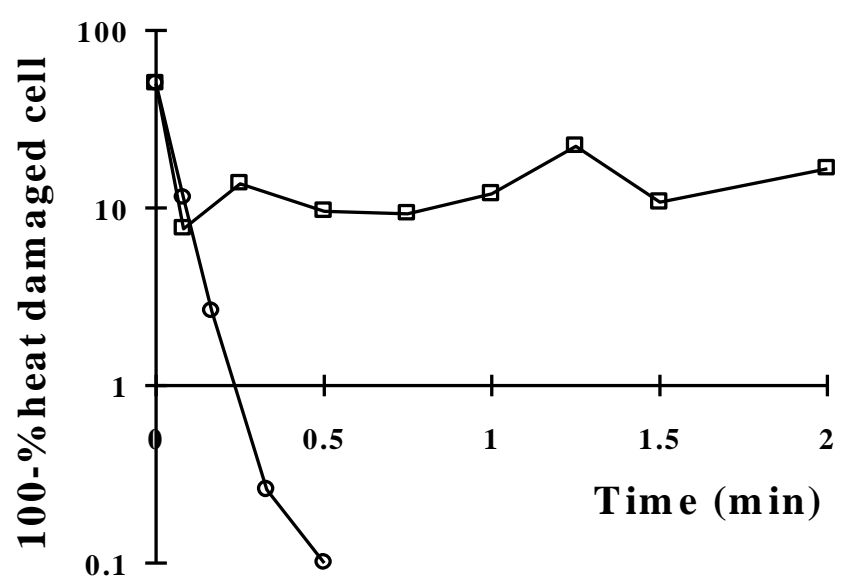


figure 4

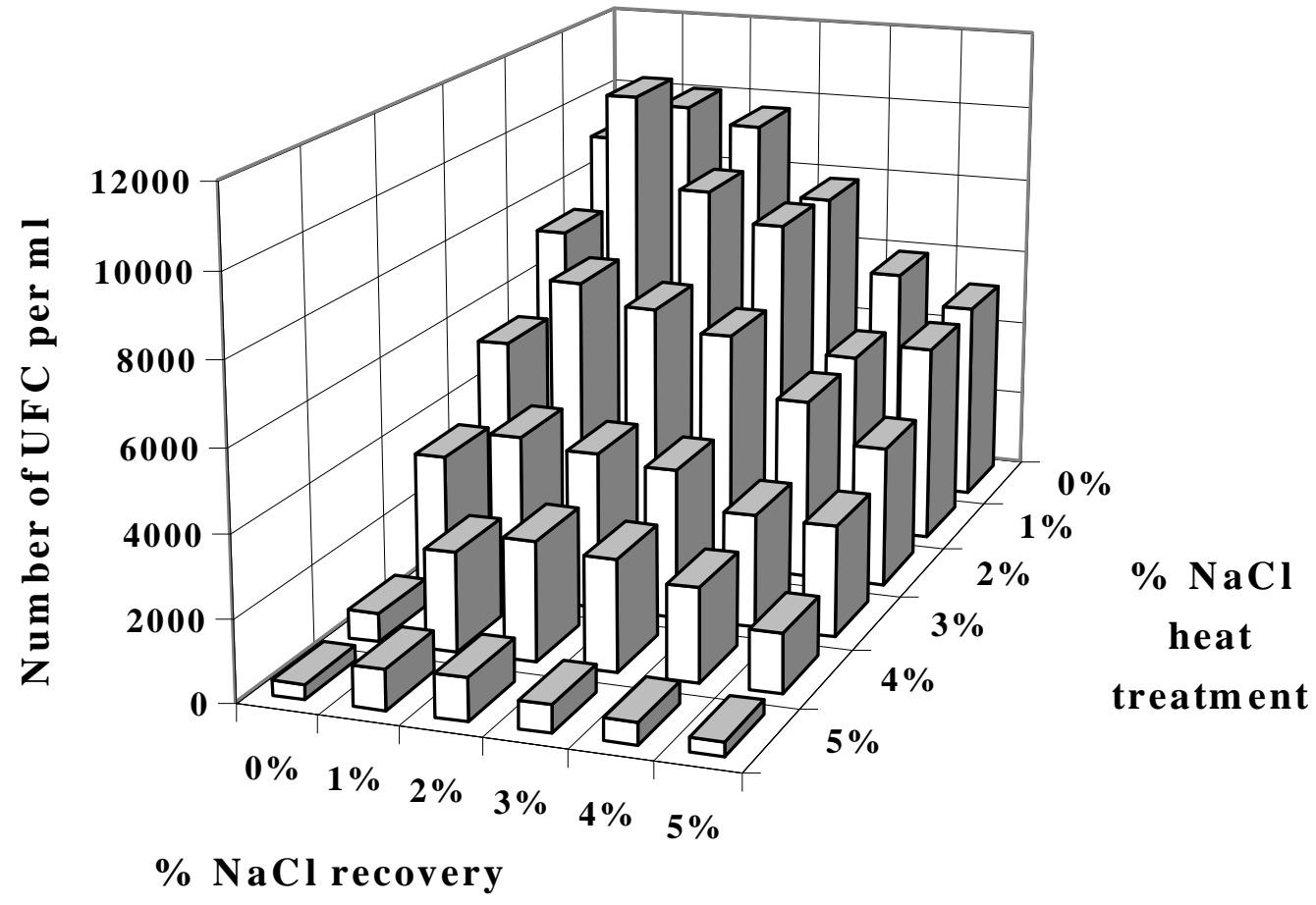


figure 5

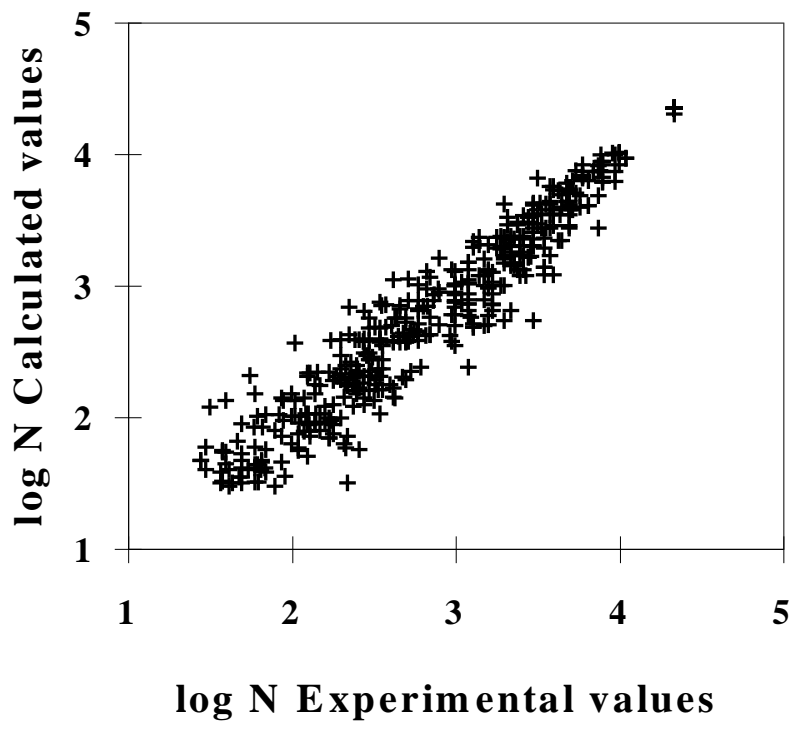

